\title{
Game as a Main Strategy in Language Education
}

\author{
Ilka Lyubenova Birova* \\ Department of Russian language, Sofia University St Kliment Ohridski, Sofia, Bulgaria \\ *Corresponding author: ilka31@abv.bg
}

Received December 15, 2013; Revised January 06, 2013; Accepted January 22, 2013

\begin{abstract}
This article is dedicated to a problem in language education - using game as a basic strategy in learning process of all age learners. The author describes main features of game as a learning method and its advantages in comparison with traditional methods. Game sustains student motivation and interest and makes education effective and pleasant. In the paper a short presentation of Suggestopedia is given, an efficient method created by Bulgarian scientist Dr G. Lozanov (1926-2012), which is based on game. In the article some terms used in language education are also discussed.
\end{abstract}

Keywords: Game, Strategy, Language Education, Suggestopedia

\section{Introduction}

This article is dedicated to an interesting problem in modern communicative language education - using game as a main strategy. The author prefers to use a term language education instead of language learning because of its more complexity and preciseness. According to Russian methodologist Passov[1] language education includes four aspects: learning, cognition, development and training. It is necessary to add two more aspects - 1) language teaching and 2) the process of teaching language and culture as a whole.

Multilingual skills in modern world are valuable and language education has a strategic importance. In this sphere of methodology there is no common accepted terms. For example, Russian and Bulgarian methodologists traditionally distinguish native-language and foreign-language education but this differentiation may be too conditional. More correct and appropriate terms could be first, second, third language education and we have to explore common mechanisms of language acquisition and practice. It does not mean that the special methodology of each different language which examines specific difficulties in process of language acquisition is not helpful. On the contrary. For example, the learning process about Russian as a second/third language for Bulgarian students of different ages is explored by the author of this article.

In methodological literature there is no consensus on the terms concerning game in language education. According to Crookal and Oxford[2], a few of the terms often used interchangeably are: simulation, games, role play, simulation play, role play simulation, and role playing game. The author of present article prefers to use terms language game and game strategy. A consensus and the use common terms in order to avoid incomprehensible problems may be necessary.

\section{Objectives and Methods}

\subsection{About Methods of Language Education}

In traditional sense language education is a hard work needed appropriate strategies and methods. Learners make efforts to understand, to repeat accurately, to manipulate newly understood language and to use the whole range of known language in conversation or written composition. At present communicative and interactive approaches are a common base of different methods in language education. For example, TPR Method of Asher, Cooperative learning and Lozanov's Suggestopedia are communicative and playful because they are based on a game strategy. The author of this article shares research methodology and practice of these methods.

\subsection{About Suggestopedia Method}

The famous Bulgarian scientist Prof. G. Lozanov in 60$\mathrm{s}$ of XX century created method Suggestopedia and experimentally proved that game is not just an element but a fundamental strategy in language education. Prof. Lozanov had been tested his method during three decades in Bulgaria, Austria, USA and many other counties. In 1978 group of experts of UNESCO recommended this method as extremely effective in language education for all age learners.[3] According to Lozanov "The main aim of teaching is not memorization, but understanding and creative solution of problems."[4]The process of language education as a game is specially organized, pleasant and effective.

The purpose of this article is to make a short description of game as a basic learning strategy in general and especially in Suggestopedia, to underline a great contribution of Lozanov's method for language education and to reveal a big value of a game for all age language learners.

In their book Richards and Rodgers describe Lozanov's method and underline learner' role and the use of role plays in it. "To assist students in the role plays and to help them detach themselves from their past learning experience, students are given new names and personal 
history within the target culture. For example, a student of English might be "the actress Anne Mackey from Kansas". Learners sit in a circle, which encourages a face-to-face exchange and active participation. Groups of learners are ideally socially homogeneous, twelve in number, and divided equally between men and women."'[5]

In his books[4,6,7] Dr Lozanov exposes basic principles of Suggestopedia and shows concrete techniques to achieve perfect results. This is a method of uncovering human hidden reserves. It means that in education process are activated conscious and unconscious mechanisms, peripheral perceptions and emotional stimulus. This is a method of free and living communication. In Lozanov's opinion it gives to the student's personality a very good impact in physical and psychological sense.[6]

In comparison with traditional teaching process suggestopedia is connected with sense of relaxation and joy. On the base of own practice and observation the author thinks that this process of learning is joyful experience. It may be examined as a great achievement in pedagogy and in humanities in general.

Arts play a very important role in this method in order to make joyful and creative atmosphere. Classical music and paintings have a strong communicative suggestion and therefore they seem to take part in language education.

Main principles in Lozanov's method are following:

1) Joyful and spontaneous activities, concentrate calmness, emotional and logical balance

2) Dynamic global: partial in global and global in partial

3) Unsuggestive understanding for spontaneous liberty of mind potential.[6]

Some typical techniques and games based on these principles are given in the article.

1) This method includes a system of funny stories, situations and special selected songs that facilities language education.

2) Teacher and students play with intonation and rhythm of speech (Ex.They read text with different intonation, rhythm and dynamic according to different emotional or social roles), role text reading

3) Reading and listening to texts, learning of new words and grammar is connected with listening of classical music (so called musical séances), seeing drama, opera and pictures.

4) Students have to guess nationality by name or some typical gesture. A point for student who raises your hand first.

5) Cities and countries. On the board a teacher gives first letter and then students guess another letters.10 points for each right letter and 50 points if a whole name is guessed. Variant of this game is to show postcards of famous places and students try to guess them. This kind of games develops oral speech skills as well as cultural knowledge of students.

6) A text is given to remember for a few minutes and then students try to reproduce it as much as possible in a correct manner. Class may be divided in teams.

7) Collective reading with stop - to develop speed of reading. First students read a text loudly, then everyone reads to oneself keeping tempo. Teacher says stop and checks text read by each student. Points are provided for the most accurate and rhythmical.

8) Teacher reads first and then students read a text with mistakes and correct them together.

9) Known text is broken to pieces of paper, mix together and then is given to students in order to put it together.

10) Students compose a story based on a given word. This game is useful in grammatical working-out.

11) Teacher or students give to a group collocations including movement or not. When a student gives a collocation with movement all students have to stand up quickly. Who ever is late to stand drops out of game. A leader stands up all the time in order to confuse another students.

12) Correct a text written without capital letters and punctuation. The quickest guess of this text gives point to a team or individually.

13) Fun dress changing. There are two teams. Two students of the teams look at each other during 1-2 minutes. Then they change some detail in clothes, for example dress or undress jacket, heat, scarf, gloves (students may go out of a classroom to change their clothing). Teams try to guess changes and game continues with another pair. Rhythm has to be quick.

14) Baton. Form 2 teams. Each student has a number. A board is divided into 2 parts - one for each team. Written questions and answers form logical text on a given topic. Each question has a number that coincides with a number of participants. They have to go to a board, to find their question and to answer it in writing. A team which participants give a right and quick answer is a winner. A reasonable text is important, written mistakes are just noted by the teacher etc.

\subsection{Game as a strategy in Language Education}

The game method as a strategy in language education is considered as a free learning activity that gives students opportunity to train and use languages with practical purpose and to use their creative skills in joyful atmosphere. Namely for that reason mostly students of all ages like games. On the base of school observation and discussion with teachers the author thinks that a great number of them underestimate game as an "unserious" activity just for relaxing. Some methodologists, for example Richard and Rodgers, do not examine a game as a method in language education [5], others think that game is just an additional device for building up the basic skills in language education at primary school.[8] In present article the author supports idea that game has to be considered as a basic strategy and method in language education not just at primary school but about all age students.

Enjoyment of games is not restricted by age. Some individuals may be less fond of games than others. But so much depends on the appropriateness of the games and the role of the player. It is generally accepted that young learners want to play games. The teenage learners might be reluctant to do it. Games which can be played in pairs or groups may be particularly useful for them. Many adult people are so anxious to learn languages in order to pass examinations needed in their work and often they look on 
games as an unnecessary. The teacher has to respect their point of view and be able to justify the use of each game in terms of meaningfulness of practice it provides.

Grozdanova noted that "second language learning is a continuous process of discovery, checking out and proving/disproving the hypothesis; it is related to problem-solving and decision-making. L2 system has to be in meaningful context"[9]. Games help a teacher to create contexts in which the language is useful and meaningful. The learners want to take part and in order to do so have to understand what others are saying or have written, and they have to speak or write in order to express their own point of view or give information. Games can encourage many learners to sustain their interest and work. Games reinforce student motivation and form creative and positive emotional atmosphere in learning process.

Games are one of the best training activities and also an active break. Many games provide repeated use of language forms. By making the language convey information and opinion, games provide the key feature of drill with the opportunity to sense the working of language as living communication. The author agree with Wright, Betteridge and Buckby that language games can be regarded as central to a teacher's repertoire. They aren`t for use solely on wet days and at the end of term![10]

Games give practice in all the skills (reading, writing, listening, speaking), in all the stages of teaching/ learning (presentation, repetition, recombination and free use of language) and for many types of communication tasks (encouraging, criticizing, agreeing, explaining etc.).

Language games are connected with notion of information and opinion gap. We speak or write because we want to pass on information or convey an opinion which we think the receiver might be interested. Very often in the language learning process there is no information gap at all and opinions are rarely questioned. The teacher usually asks a question which the learner knows the teacher can answer. The teacher is more interested in the form than in the content of what the learner says. In the opposite, the information gap stimulates and motivates students to use language in order to find information and express your opinion.

The following is an example of one of the best known of the information gap games. Describe and draw a picture: One person has a picture and does not show it to his partner. There is an information gap. The first learner then tries to describe the picture so that the second learner can draw it. Language is used to bridge the gap. The picture drawn by the second learner is then visible evidence of whether the gap has been closed.

The essential ingredient of a game is challenge. It is very important that games are based on speech and reflection activity. For example, if the teacher asks students to describe a house in the forest (given on a picture) it does not stimulate them for speaking activity because there is no challenge to student's imagination and thinking. This is not a communicative task. If the teacher says: Imagine who does live in this house and what happens now there - It is a communicative task based on thinking and speaking challenge and activity. It is typical then for a language game. Challenge is not synonym with competition but many of the games are competitive and need cooperation or team work to solve problems. This kind of games dives an opportunity to develop speaking skills as well as students' social skills especially in group work. The problems have to be related to the students' age and interests. For example, appropriate discussion with teenagers is on following themes: Are adults always right? How much does one need? What is the most beautiful place on earth etc.

\subsection{Kinds of Language Games}

There are many different kinds of language games according to the specific tools, skills and activities. For example: speaking, listening, writing games, games with toys, pictures, objects, cards etc. In recent years there are many books and papers dedicated to description of different language games.[10],[11],[12],[13],[14]. As an illustration is given a picture game which develops imagination and speaking activity.

Game "That's an unusual view".

Language: Naming and describing objects ( It's a ...) or expressing ignorance (I don`t know or I've no idea or It could be...). In variation, the phrase It's a part of...

Skills: Listening and speaking

Control: Guided

Level: Beginners

Time: 10-15 min.

Materials: board; In the variations, magazine pictures

Preparation: Prepare a few drawings of unusual views of common objects on sheets of paper.

Procedure: Class work, optionally leading to group work. Draw several examples of unusual views of objects on the board. Ask what they are.

Example:

Teacher: What's this?

Learner 1: It`s a woman`s face.

Teacher: She hasn't got any eyes or nose!

Learner 2: It's a beefburger.

Teacher: It's a beefburger from above.

Ask the learners to prepare ideas of their own for a few minutes and then to challenge the rest of the class or group. If the learners cannot answer, they have to say "I don't know or I've no idea".

Variation: Use the picture from magazines etc. These may be unusual views of objects which you have cut out. If you show parts of objects the learners should say part of (It's a part of a wheel).

This example shows that game provides perfect conditions to train and repeat language difficulties (in this case using prepositions and making questions), to challenge imagination and reflection and to enjoy.

The author wants to underline an importance of role play in language education. In his book on this subject Gilian Porter Ladousse says: "Play means that the role is taken on in a safe environment in which students are as inventive and playful as possible."[15] This kind of game can be efficient if it is connected with student interests and needs in order to motivate them in learning process.

Different kinds of game may be examined as a variant of cognitive functional approach, a realization of usagebased theory[16]. For example, Tsvetkova shares this approach and presents a simple English structure with present continuous tense as a cognitive model. This model 
consists of the parts of the cat - head, neck, body and tail. The head symbolizes the subject which also is moving. The neck symbolizes the finite form (auxiliary verbs) in the sentence. It is relationship between a subject and a verb. The body symbolizes the verb. The tail symbolizes the inflection - ing. It is always attached to the body, to the basis of the verb to form the present participle. This way is appropriate to acquire linguistic information by young learners at primary school. This approach demonstrates in images an hierarchical relationship in English sentence and facilitates a learning process. [17]

It is important to note that new educational resources in Internet are game based. They are situated in bright image context, with nice music background, playful word and phrase repetition in different situations and very often there are typical cultural elements.[18] All these are components of game as a strategy and these resources will be develop more and more in the future. In a present language learning process e-resources have to be examined as an important part of education and selfeducation that has to be combined with traditional resources.

In her teaching practice the author of this article applies a game method in its traditional and e-versions. In a course of lections on Methodology of foreign language education the game has an important place, as well as a knowledge about Suggestopedia method. In her academic activity at the Sofia University there are 2 specialized courses: a first course with students of Pedagogy is about playful interaction in language (about different languages) education of children of 7-10 years old, and a second course with students of Russian philology is named "Game in Russian language learning at school". Students prepare presentations on game method in language learning process and give lessons on it at school. There is a collaboration in a process of collecting language game about different languages. Interaction of theory and practice activity is very useful both for students and for the teacher.

\subsection{Organization of Language Game}

The form of class organization is very important in language games. The teacher has to decide which of the form is appropriate: class, individual, pair and group work. Good organized games mean that each learner has sufficient speech practice in using language.

Pair work is easy and fast to organize. It provides opportunities for intensive listening and speaking practice. Pair work is better than group work if there are discipline problems. Some methodologists recommend to organize games in pair or general class work, rather than in group work. If there is to be challenge between groups, they should be of mixed ability. Many teachers consider it advisable to have a group leader but there are opinions that groups can operate perfectly well without a group leader. The leader would normally be one of the more able learners. His role is to ensure that the game or activity is properly organized and to act as an intermediary between learners and teacher. The teacher's role, once the groups are in action, is to go from group to group listening in, contributing and, if necessary, correcting.
It is essential that the learners are totally familiar with the games they are asked to play. It is helpful if they are familiar with the rules of the game in their own language. New games are normally introduced in the following way:

1) Explanation by the teacher to the class

2) Demonstration of parts of the game by the teacher and one or two learners

3) Trial by a group in front of the class

4) Any key language or instructions written on the board.

5) First try by groups

6) Key language removed from the board

If the teacher is unfamiliar with the use of language teaching games then it is advisable to introduce them slowly as supplementary activities. Once the teacher is familiar with a variety of games, they can be used as a substitute for parts of the course.

Many teachers believe that competition should be avoided. It is possible to play the majority of games with a spirit of challenge to achieve, rather than "to do someone else down." It is also wrong to compel an individual to participate. Learners reluctant to do this might be asked to act as a judge and scorers.

It is advisable to stop a game and change to something else before the learners become tired of it. In this way their good will and concentration are retained.

The teacher's attitude and language are important in the process of game. The teacher should never interrupt a game which is flowing successfully in order to correct a mistake in language use. It would suggest that the teacher is more concerned with form than the exchange of ideas. In general, it better to note the error and to comment on it later, when a game is finished.

\section{Results}

In order to use game as an effective strategy in process of language education each teacher has to answer the following questions.

1) Will the game be relatively easy for you to organize in the classroom?

2) Is it likely to interest the particular group of learners you have in mind?

3) Are you forcing language activity into the game?

4) Is the amount of language and the type of use enough to justify the use of the game?

If your answer is yes to each of these questions, then the game you have in mind is a highly efficient means of satisfying learners` needs.

The teacher has to decide which form of interaction during games is the most appropriate and structure them effectively.

Game strategy may be considered as a basic element of conceptual matrix of communicative language teaching[19]. Game is one of the basic communicative methods in language education. Lozanov's Suggestopedia is a perfect illustration of a game based education that develops hidden human reserves and creative skills.

\section{Conclusions}


In present language methodology it is necessary to realize a role of game in language education. A perfect example of game philosophy in education is the Suggestopedia method. The process of learning in it is motivating and interesting both for students and teacher. The reason is special game strategy and the atmosphere it can create. According to Lozanov "the whole process of learning is a game, special, pleasant, game of two plans (conscious and unconscious). Play this game! Life is a game with its emotions and ambitions!'[6]

The author of this article believes that game in its traditional and e-version has to be considered and explored not as an additional device but as a main strategy in language education both for children and adults. Because the game maintains learners' interest and motivation, facilitates the process of teaching and learning and converts language education into real intellectual and emotional experience developing student personality.

\section{Reference}

[1] Passov, E. The Theory and Technology of Foreign Language Education as a Science, In: Russian Language in the centre of Europe, Slovakia, Banska Bistritza, 2003,No .6, p.74-75

[2] Crookal, D. and Oxford, R. L., Linking Language Learning And Simulation/Gaming . In D.Crookal and R. L. Oxford (Eds.), Simulation, Gaming, and Language Learning, New York: NewburyHouse, 1990, p. 3

[3] Journal of the Society for Accelerative Learning and Teaching, Vol. 3, Number 3, Fall, 1978, p.211

[4] Lozanov, G. Suggestology and Outlines of Suggestopedia; Gordon and Breach, New York, London, Paris, 1978, p.235
[5] Richards, J., T. Rodgers, Approaches and Methods in Language Teaching. A description and analysis, Cambridge Language Teaching Library, Prosveta, 1992, p.149

[6] Lozanov, G. Suggestopedia - unsuggestive education, Bulgaria, Sofia University Publishing house, 2005, p. 90-96

[7] Lozanov G. and E. Gateva. Foreign Language Teacher's Suggestopedic Manual; Gordon and Breach Science Publishers S. A., New York, 1988

[8] Patovska, M. The game at primary school - an additional device for building up the basic skills in English, In International seminar "Education for all", Shumen, 2010

[9] Grozdanova, L. Fresh Ideas in ELT, Sofia, 2003, p.159

[10] Wright, A., D. Betteridge and M. Buckby Games for Language Learning, Cambridge University Press, 1989

[11] Lyubenova, (Birova) I. Possibilities of Early Foreign Language Education (English and Russian), Bulgaria, Sofia University Publishing house, 2004.

[12] Scott, W. A., Ytreberg L., Teaching English to Children, Longman, 1990

[13] Lee, W. Language Teaching Games and Contests, Oxford University Press, 1990

[14] Birova, I. Language Games in Education of Russian as a Foreign Language, In: Collection of University "Chernorizets Hrabar", Bulgaria, Varna, 2010

[15] Gilian, Porter Ladousse Role play, Oxford University Press, 1989

[16] Tomasello, M. Acquiring linguistic constructions In Kuhn D., R. Siegler (eds), Handbook of Child Psychology. New York: Wiley, 2006

[17] Tsvetkova, M. Can Cognitive functional Approach foster young learners' foreign language acquisition? In: Language, cognition, communication (ed. R. Todorova, T. Seizova-Nankova), Konstantin Preslavski University Press, Shumen, 2010, p.70-71

[18] E-resources http://learnenglishkids.britishcouncil.org/en/songs/quiet-please http://www.solnet.ee/games/g5_53.html http://www.youtube.com/watch?v=ATfRpqQAdCg\&feature=Play Play\&p=927286C29A9B3AA2\&playnext=1\&playnext_from=PL \&index $=4$

[19] Simeonova, J. Conceptual matrix of communicative language teaching / Foreign Language Teaching Journal, Sofia, 2011, No.6 